\title{
L-Citrulline Levels in Watermelon Cultigens Tested in Two Environments
}

\author{
Angela R. Davis ${ }^{1}$, Charles L. Webber III, and Wayne W. Fish \\ Wes Watkins Agricultural Research Laboratory, USDA-ARS, P.O. Box 159, \\ Lane, OK 74555
}

Todd C. Wehner

Department of Horticultural Science, North Carolina State University, Raleigh, NC 27695-7609

\section{Stephen King \\ Department of Horticultural Sciences, Texas A\&M University, College Station, TX 77843}

\section{Penelope Perkins-Veazie \\ Plants for Human Health Institute, North Carolina State University, Kannapolis, NC 28083}

Additional index words. Citrullus lanatus, phytonutrients, amino acids, genotype by environment, fruit quality

\begin{abstract}
Producers of fresh fruits and vegetables face increasing production costs and international market competition. Growers who can offer high-quality watermelons [Citrullus lanatus (Thumb.) Matsum. \& Nakai] that are also highly nutritious will have better market opportunities. To accomplish that, germplasm must be identified that has enhanced phytonutrient levels. Surprisingly, there is little information on the genetics of nutritional quality in watermelon. The present study was performed on 56 watermelon cultivars, breeding lines, and PI accessions (hereafter collectively referred to as cultigens) to determine the importance of genotype and environmental effects on L-citrulline concentration in fruit, an amino acid that helps regulate blood pressure. Our results demonstrated that $L$-citrulline concentration was affected by environment and the amount of environmental effect varies among cultigens. The mean of fruit tested in Lane, OK, was $3.10 \mathrm{mg} \cdot \mathrm{g}^{-1}$ fresh weight and in College Station, TX, it was $1.67 \mathrm{mg} \cdot \mathrm{g}^{-1}$ fresh weight. All cultigens had a higher mean L-citrulline concentration when grown in Lane, OK, instead of College Station, TX. Additionally, the L-citrulline concentration varied considerably within cultigens; i.e., 'Congo' had a 1.26 to $7.21 \mathrm{mg} \cdot \mathrm{g}^{-1}$ fresh sample deviation. The cultigen 'AU-Jubilant' had the most stable L-citrulline concentration $\left(2.23\right.$ to $4.03 \mathrm{mg} \cdot \mathrm{g}^{-1}$ fresh deviation) when tested from one location. Environment did not significantly increase within-genotype variation (average SE of 10 cultigens tested at each location was $\pm \mathbf{3 5 . 3} \%$ for College Station, TX, and $\pm \mathbf{3 2 . 9 \%}$ for Lane, OK). L-citrulline concentration did not correlate with watermelon type (open-pollinated or F1 hybrid) or flesh color (red, orange, salmon yellow, or white). Differences among cultigens for $L$-citrulline were large (1.09 to $4.52 \mathrm{mg} \cdot \mathrm{g}^{-1}$ fresh sample). The cultigens with the highest L-citrulline concentration were 'Tom Watson', PI 306364, and 'Jubilee'. These could be used to develop cultivars having a high concentration of L-citrulline.
\end{abstract}

Watermelon is the number two fresh vegetable crop in the world in terms of area harvested and total production (FAOSTAT, 2009). Recently, it has been identified as a healthy food because it is high in the carotenoid, lycopene. Although watermelon is the leading fruit and vegetable source of lycopene, it also contains other antioxidants and

Received for publication 1 Aug. 2011. Accepted for publication 8 Sept. 2011.

This project was partially funded by the National Watermelon Promotion Board and the National Watermelon Association.

We thank Amy Helms and Cody Sheffield for technical help.

${ }^{1}$ To whom reprint requests should be addressed; e-mail angela.davis@lane-ag.org. amino acids that have health-promoting activities. Fruits and vegetables contain many compounds that work synergistically. Boileau et al. (2003) indicated that lycopene alone is not responsible for reducing prostate cancer associated with increased tomato intake. Because tomatoes contain the glycoalkaloid tomatine, a demonstrated anticarcinogen, as well as several well-known phenolic compounds such as quercitin, this finding is not unexpected and demonstrates the importance of maintaining the other nutritional compounds in fruits and vegetables.

Amino acids have well-established individual roles in disease prevention. Arginine, an essential amino acid, functions as one of the 20 building blocks of proteins and in free form as a physiological amino acid. L-citrulline is a physiological amino acid endogenous to most living systems. These amino acids are directly involved in clearing excess metabolic ammonia from the human body and are indirectly involved in cardiovascular function, immunostimulation, and protein metabolism (Curtis et al., 2005). Ingested arginine is cleared by hepatic cells, but L-citrulline is not and can serve as an arginine source in other parts of the body.

Watermelon is rich in citrulline (Tedesco et al., 1984) but differences among cultivars have not been adequately studied nor have effects of production environments. Fish and Bruton (2010) reported that one cultivar grown at two locations had little variation in flesh concentration of L-citrulline. Tarazona-Díaz et al. (2011) reported values on five lines (four of them triploid seedless cultivars) grown at one location with a mean citrulline concentration in watermelon flesh of $2.33 \mathrm{mg} \cdot \mathrm{g}^{-1}$; they also demonstrated that the seeded cultivar had the least L-citrulline concentration in flesh tissue. In an earlier report, 14 watermelon cultivars had 0.5 to $3.6 \mathrm{mg} \cdot \mathrm{g}^{-1}$ fresh weight of citrulline with an average concentration of $2.4 \mathrm{mg} \cdot \mathrm{g}^{-1}$ (Rimando and Perkins-Veazie, 2005). Those authors reported less L-citrulline in red-fleshed fruit than in yellow or orange, but only a small sample size (three fruit for each variety) was used, and because the fruit tested were grown at multiple locations, it is difficult to assess the genotype and environmental effect on L-citrulline concentration in those fruits. Liu et al. (2010) reported that greenhouse-grown watermelon fruit of nine induced autotriploid hybrids had higher Lcitrulline values than their diploid and induced autotetraploid parents. Fish and Bruton (2010) and Liu et al. (2010) reported that the concentration of L-citrulline was highest at peak ripeness.

Humans can effectively absorb L-citrulline from watermelon, which also increases plasma arginine levels (Collins et al., 2007; Mandel et al., 2005). Recently, subjects consuming watermelon or synthetic citrulline as a drink, combined with exercise, had reduced arterial blood pressure compared with a placebo (Figueroa et al., 2011). The heightened importance of watermelon as a source of bioactive compounds such as L-citrulline highlights the need for a better understanding of the genetic control of this amino acid and other phytonutrients in watermelon. The current study expands on a preliminary trial by Davis et al. (2010) and was designed to measure effects of genotype and environment on L-citrulline accumulation in watermelon. A diverse collection of watermelon germplasm was screened to identify cultigens having a high concentration of L-citrulline that was stable over environments.

\section{Materials and Methods}

Plant material. Fifty-six (Table 1) watermelon cultigens (open-pollinated and hybrids) grown in Lane, OK (Bernow fine-loamy, siliceous, thermic, Glossic Paleudalf soil) were arranged in a randomized complete block design with four replications. Plant management 
Table 1. L-citrulline concentrations averaged by cultigen across replications at Lane, OK. ${ }^{\mathrm{z}}$

\begin{tabular}{|c|c|c|c|c|c|}
\hline Cultigen & $\begin{array}{c}\text { Mean ( } \mu \mathrm{g} \text { L-citrulline/g } \\
\text { fresh wt) }\end{array}$ & SD & $\begin{array}{l}\text { Plant } \\
\text { type }\end{array}$ & $\begin{array}{l}\text { Flesh } \\
\text { color }\end{array}$ & $\begin{array}{l}\text { Number of } \\
\text { fruit tested }\end{array}$ \\
\hline Tom Watson & $4.52 \mathrm{a}^{\mathrm{y}}$ & 0.72 & $\mathrm{OP}^{\mathrm{x}}$ & $\mathrm{R}^{\mathrm{w}}$ & 2 \\
\hline PI 306364 & $3.70 \mathrm{abc}$ & 0.25 & OP & $\mathrm{R}$ & 2 \\
\hline Jubilee & $3.57 \mathrm{abcd}$ & 1.06 & $\mathrm{OP}$ & $\mathrm{R}$ & 26 \\
\hline Charleston Gray & 3.56 abcde & 0.93 & OP & $\mathrm{R}$ & 50 \\
\hline Graybelle & 3.55 abcde & 1.09 & OP & $\mathrm{R}$ & 11 \\
\hline Early Canada & 3.47 abcde & 1.09 & $\mathrm{OP}$ & $\mathrm{R}$ & 14 \\
\hline Congo & 3.47 abcde & 1.47 & OP & $\mathrm{R}$ & 30 \\
\hline King \& Queen & $3.46 \mathrm{abcde}$ & 1.13 & $\mathrm{OP}$ & $\mathrm{R}$ & 36 \\
\hline Early Arizona & 3.42 abcde & 1.41 & OP & $\mathrm{R}$ & 19 \\
\hline Navajo Sweet & 3.40 abcde & 1.20 & $\mathrm{OP}$ & $\mathrm{R}$ & 13 \\
\hline Starbrite F1 & 3. abcde 35 & 0.94 & Hy & $\mathrm{R}$ & 36 \\
\hline Sangria F1 & 3.30 abcde & 0.86 & Hy & $\mathrm{R}$ & 24 \\
\hline Legacy F1 & 3.30 abcde & 0.99 & Hy & $\mathrm{R}$ & 45 \\
\hline Sugar Baby & 3.29 abcde & 1.13 & $\mathrm{OP}$ & $\mathrm{R}$ & 26 \\
\hline Crimson Sweet & 3.23 abcde & 0.96 & OP & $\mathrm{R}$ & 25 \\
\hline Regency F1 & 3.22 abcde & 1.12 & Нy & $\mathrm{R}$ & 37 \\
\hline Yellow Crimson & 3.22 abcde & 1.37 & OP & CY & 26 \\
\hline Sweet Princess & 3.21 abcde & 1.00 & OP & $\mathrm{R}$ & 25 \\
\hline Big Crimson & 3.17 abcde & 0.99 & $\mathrm{OP}$ & $\mathrm{R}$ & 43 \\
\hline Carolina Cross \#183 & 3.17 abcde & 1.27 & OP & $\mathrm{R}$ & 13 \\
\hline Stars-N-Strips F1 & 3.16 abcde & 0.98 & Нy & $\mathrm{R}$ & 40 \\
\hline Black Diamond & 3.13 abcde & 0.87 & $\mathrm{OP}$ & $\mathrm{R}$ & 11 \\
\hline Quetzali & 3.13 bcde & 0.86 & OP & $\mathrm{R}$ & 32 \\
\hline Mountain Hoosier & 3.10 bcde & 1.01 & OP & $\mathrm{R}$ & 20 \\
\hline Mickylee & 3.10 bcde & 0.91 & $\mathrm{OP}$ & $\mathrm{R}$ & 9 \\
\hline Allsweet & 3.09 bcde & 0.97 & OP & $\mathrm{R}$ & 18 \\
\hline Calhoun Gray & 3.08 bcde & 1.09 & OP & $\mathrm{R}$ & 41 \\
\hline Georgia Rattlesnake & 2.95 bcdef & 0.95 & OP & $\mathrm{R}$ & 9 \\
\hline AU-Jubilant & 2.94 bcdef & 0.53 & OP & $\mathrm{R}$ & 12 \\
\hline Stone Mountain & $2.90 \mathrm{bcdef}$ & 1.03 & OP & $\mathrm{R}$ & 36 \\
\hline Fiesta F1 & 2.89 bcdef & 0.94 & Hy & $\mathrm{R}$ & 42 \\
\hline Hopi Red Flesh & 2.88 bcdef & 1.22 & $\mathrm{OP}$ & $\mathrm{R}$ & 23 \\
\hline Tendersweet Orange Flesh & $2.87 \mathrm{bcdef}$ & 0.98 & OP & $\mathrm{O}$ & 16 \\
\hline Sugarlee & 2.83 bcdefg & 1.02 & OP & $\mathrm{R}$ & 29 \\
\hline Desert King & 2.83 bcdefg & 1.29 & OP & SY & 20 \\
\hline Calsweet & 2.78 bcdefg & 0.98 & OP & $\mathrm{R}$ & 49 \\
\hline North Carolina Giant & $2.67 \mathrm{bcdefgh}$ & 0.97 & OP & $\mathrm{R}$ & 30 \\
\hline Minilee & $2.53 \mathrm{bcdefgh}$ & 0.87 & OP & $\mathrm{R}$ & 34 \\
\hline PI 385963 & $2.53 \mathrm{bcdefgh}$ & $\mathrm{-v}^{\mathrm{v}}$ & OP & $\mathrm{R}$ & 1 \\
\hline PI 225557 & 2.52 bcdefgh & 0.87 & OP & $\mathrm{R}$ & 2 \\
\hline Royal Flush F1 & $2.49 \mathrm{bcdefgh}$ & 1.06 & Hy & $\mathrm{R}$ & 33 \\
\hline PI 306367 & 2.46 bcdefghi & $\mathrm{-v}^{\mathrm{v}}$ & OP & $\mathrm{R}$ & 1 \\
\hline Peacock WR-60 & 2.42 bcdefghi & 1.13 & OP & $\mathrm{R}$ & 29 \\
\hline Golden Midget & 2.39 bcdefghi & 0.81 & OP & $\mathrm{R}$ & 19 \\
\hline PI 186974 & 2.34 cdefghi & 1.35 & OP & $\mathrm{R}$ & 6 \\
\hline PI 255139 & 2.26 defghi & $\mathrm{-v}^{\mathrm{v}}$ & OP & $\mathrm{R}$ & 1 \\
\hline PI 189317 & 2.18 efghi & 0.62 & OP & W & 3 \\
\hline PI 161373 & $1.65 \mathrm{fghi}$ & 0.24 & OP & $\mathrm{R}$ & 2 \\
\hline PI 164993 & 1.46 ghi & $\mathrm{-v}^{\mathrm{v}}$ & OP & $\mathrm{R}$ & 1 \\
\hline PI 181742 & $1.38 \mathrm{hi}$ & 0.62 & OP & $\mathrm{R}$ & 6 \\
\hline PI 162667 & $1.35 \mathrm{hi}$ & 0.35 & OP & $\mathrm{R}$ & 10 \\
\hline Low Sugar Watermelon 194 & $1.22 \mathrm{i}$ & 1.02 & OP & $\mathrm{R}$ & 7 \\
\hline PI 164992 & $1.21 \mathrm{i}$ & $\mathrm{C}^{\mathrm{v}}$ & $\mathrm{OP}$ & $\mathrm{R}$ & 1 \\
\hline Low Sugar Watermelon 177 & $1.09 \mathrm{i}$ & 0.52 & $\mathrm{OP}$ & $\mathrm{R}$ & 3 \\
\hline
\end{tabular}

${ }^{\mathrm{z}}$ Cultigens shaded in gray were grown at two locations and appear in Table 2 . The values were estimated using a thin-layer chromatography plate method.

yAny two means within a column not followed by the same letter are significantly different at $P \leq 0.05$. ${ }^{x}$ Type of watermelon: $\mathrm{OP}=$ open-pollinated line, $\mathrm{Hy}=$ hybrid line.

wFlesh color for each cultigen: $\mathrm{R}=$ red or pink, $\mathrm{SY}=$ salmon yellow, $\mathrm{CY}=$ canary yellow, $\mathrm{O}=$ orange, and $\mathrm{W}=$ white fruit.

'Indicate SD was not calculated because only one fruit was tested.

provided was as outlined in Motes and Cuperus (1995). Plants were transplanted onto bare, raised beds, were irrigated as needed (at the first signs of water stress), and fertigated bimonthly. To assess environmental effects, 10 watermelon cultigens (Table 2) were also grown at College Station, TX [Zack very fine sandy loam (fine, smectitic, thermic Udertic Paleustalfs)] using the same planting scheme. Pre-plant fertilizer was added according to soil test results and plant care provided as outlined in Masabni et al. (2011). The plants were transplanted on 21 May onto black plastic mulched beds that were drip-irrigated using a timer to irrigate daily based on evapotranspiration rates. All plants were grown during the summer of 2010 and were harvested throughout the season. Flesh from all fruit harvested from Lane, OK, and from a representative collection of fruit from College Station, TX, were collected from ripe fruit only. Maturity was assessed by external and internal characteristics (i.e., waxiness, tendril death, Brix, firmness, seed maturity). A digital refractometer was used to determine Brix. Samples were collected from the center of each fruit, pureed for 3 min with a Polytron PT 10-35 grinder (Kinematica AB, Lucerne, Switzerland) set at medium speed and stored at $-80{ }^{\circ} \mathrm{C}$ until analyzed for L-citrulline.

Citrulline quantification by thin-layer chromatography plates. L-citrulline was analyzed using a thin-layer chromatography (TLC) plate method, which was a slight modification of a Brenner and Niederwieser (1960) method. L-citrulline was quantified on the basis of an L-citrulline standard (Sigma-Aldrich, St. Louis, MO). Briefly, 40-g samples were pureed using a Brinkmann Polytron Homogenizer (Brinkmann Instruments, Inc., Westbury, NY) with a $20 \mathrm{~mm}$ O.D. blade. One milliliter of the liquid puree was centrifuged at $15,800 g_{n}$ for $10 \mathrm{~min}$ to remove debris. Supernatants were diluted to make a $10 \%$ and a $20 \%$ solution in deionized water. Ten microliters of the diluents were loaded on a $20 \times 20-\mathrm{cm}$ silica gel matrix $(200-\mu \mathrm{m}$ layer thickness, 5- to $17-\mu \mathrm{m}$ particle size) TLC plate (SigmaAldrich). The spots were air-dried and amino acids were resolved using a solvent (2:1:1 n-butanol:acetic acid:deionized water). Plates were developed with $0.2 \%$ ninhydrin in ethanol by baking at $95{ }^{\circ} \mathrm{C}$ for 5 to $10 \mathrm{~min}$. Densitometric scans of the citrulline spots were visualized and calculated against standards using a Kodak Image station (Model 440CF; Eastman Kodak, Rochester, NY). Data are in $\mathrm{mg} \cdot \mathrm{g}^{-1}$ fresh weight, because $1 \mathrm{~mL}$ of watermelon puree is very nearly and consistently $1 \mathrm{~g}$.

Citrulline quantification by highperformance liquid chromatography. Frozen tissue was thawed and then centrifuged at $10,000 g_{\mathrm{n}}$ for $10 \mathrm{~min}$ at $15{ }^{\circ} \mathrm{C}$ to remove insoluble components. L-citrulline was quantified by a method first reported in Chang et al. (1983) and subsequently modified by Krause et al. (1995) and by Sethuraman et al. (2004) for the determination of physiological amino acids and biogenic amines by reversed-phase high-performance liquid chromatography (HPLC) separation of their dabsyl derivatives. The Sethuraman et al. (2004) method was recently modified by Fish and Bruton (2010) for extraction and quantification of physiological amino acids from cucurbits. The gradient program of Sethuraman et al. (2004) was used. Separation/quantification was performed on a Varian ProStar tenary solvent HPLC system equipped with an autosampler and diode array detector (Varian, Walnut Creek, CA). A $250 \mathrm{~mm} \times$ $4 \mathrm{~mm}, 5-\mu \mathrm{m}$ Luna ${ }^{\mathrm{TM}} \mathrm{C} 18$ reversed-phase column was used (Phenomenex, Torrance, CA) at $50{ }^{\circ} \mathrm{C}$ and at a flow rate of $1.0 \mathrm{~mL} \cdot \mathrm{min}^{-1}$. The dabsyl derivatives eluting from the column were monitored by absorbance at $468 \mathrm{~nm}$. Dabsyl chloride [4-(4-dimethylaminophenylazo) benzenesulfonyl chloride] was purchased from Pierce (Pierce Biotechnology, Rockford, IL), and the amino acids used for calibration of the method were purchased from SigmaAldrich as a commercial 18 amino acid calibration mixture. The physiological amino 
acids, L-citrulline, L-glutamine, L-asparagine, and $\gamma$-aminobutyric acid (all purchased from Sigma-Aldrich), were quantitatively prepared individually and as a mixture. The suspected identity of L-citrulline in watermelon was confirmed by cochromatography of the extract with the authentic individual amino acid. Calibration curves for each amino acid ranged between 0.2 and $1.6 \mathrm{nM}$ of the amino acid on the column, and the unknowns were diluted to this concentration range for analysis.

Data analysis. Data were subjected to analysis of variance using PROC GLM (Version 9.1.3; SAS, Cary, NC). Responses to main effects were determined and means separated using the Ryan-Einot-Gabriel-Welsch multiple F test.

\section{Results and Discussion}

Comparison of high-performance liquid chromatography to the modified thin-layer chromatography plate method. Amino acid analysis of protein hydrolysates is generally considered a routine procedure; however, quantification of physiological L-citrulline is often complicated by the presence of L-glutamine. The method used here estimates L-citrulline and L-glutamine together. Because ripe water- melon contains from three to 10 times more Lcitrulline than L-glutamine (Fish and Bruton, 2010), the amount of L-glutamine in the samples should not adversely affect the reliability of comparisons of citrulline levels among samples. To verify this, 14 watermelon samples were compared using the TLC plate method and HPLC methods mentioned previously (Fig. 1). Although the TLC plate method used is not as precise as HPLC, and although L-glutamine might increase the estimated L-citrulline when using the TLC plate method, this method gave L-citrulline concentrations in the same general range as HPLC. This range was adequate for estimating L-citrulline within a set of watermelon samples when compared with another set of watermelon samples. As a practical estimate of the average deviation from the HPLC values, the mean absolute deviation of the 14 samples from its HPLC value were determined to be $0.35 \mathrm{mg} \cdot \mathrm{g}^{-1}$. Considering a $0.35 \mathrm{mg} \cdot \mathrm{g}^{-1}$ deviation in the 14 samples, which ranged from no detectable citrulline to samples containing $1.8 \mathrm{mg} \cdot \mathrm{mL}^{-1}$, this suggests an inaccuracy of $\approx 20 \%$. This is an acceptable amount of error for use as a screening tool to find large changes in citrulline concentrations resulting from genetics or environmental effects. However, for exact

Table 2. L-citrulline concentration for cultigens produced at two locations and averaged across locations. ${ }^{\mathrm{Z}}$

\begin{tabular}{|c|c|c|c|}
\hline Cultigen & $\begin{array}{c}\text { Lane, OK } \\
\text { Mean }(\mu \mathrm{g} \mathrm{L} \text {-citrulline/g } \\
\text { fresh wt) }\end{array}$ & $\begin{array}{c}\text { College Station, TX } \\
\text { Mean ( } \mu \mathrm{g} \text { L-citrulline/g } \\
\text { fresh wt) }\end{array}$ & $\begin{array}{c}\text { Combined locations } \\
\text { Mean }(\mu \mathrm{g} \mathrm{L} \text {-citrulline/g } \\
\text { fresh wt) }\end{array}$ \\
\hline Charleston Gray & $3.56 \mathrm{a}^{\mathrm{y}}$ & $1.06 \mathrm{c}$ & $2.31 \mathrm{abc}$ \\
\hline Starbrite F1 & $3.35 \mathrm{ab}$ & $2.50 \mathrm{a}$ & $2.93 \mathrm{a}$ \\
\hline Sangria F1 & $3.30 \mathrm{abc}$ & $1.65 \mathrm{abc}$ & $2.48 \mathrm{abc}$ \\
\hline Crimson Sweet & $3.23 \mathrm{abc}$ & $2.11 \mathrm{ab}$ & $2.67 \mathrm{ab}$ \\
\hline Yellow Crimson & $3.22 \mathrm{abc}$ & $1.39 \mathrm{bc}$ & $2.3 \mathrm{abc}$ \\
\hline Allsweet & $3.09 a b c$ & $1.58 \mathrm{bc}$ & $2.33 \mathrm{abc}$ \\
\hline Hopi Red Flesh & $2.88 \mathrm{abc}$ & $1.45 \mathrm{bc}$ & $2.16 \mathrm{bc}$ \\
\hline $\begin{array}{l}\text { Tendersweet Orange } \\
\text { Flesh }\end{array}$ & $2.87 \mathrm{abc}$ & $1.83 \mathrm{abc}$ & $2.35 \mathrm{abc}$ \\
\hline North Carolina Giant & $2.67 \mathrm{bc}$ & $1.52 \mathrm{bc}$ & $2.09 \mathrm{c}$ \\
\hline Minilee & $2.53 \mathrm{c}$ & $1.67 \mathrm{abc}$ & $2.1 \mathrm{bc}$ \\
\hline
\end{tabular}

${ }^{2}$ The values were estimated using a thin-layer chromatography plate method.

${ }^{\mathrm{y}}$ Any two means within a column not followed by the same letter are significantly different at $P \leq 0.05$.

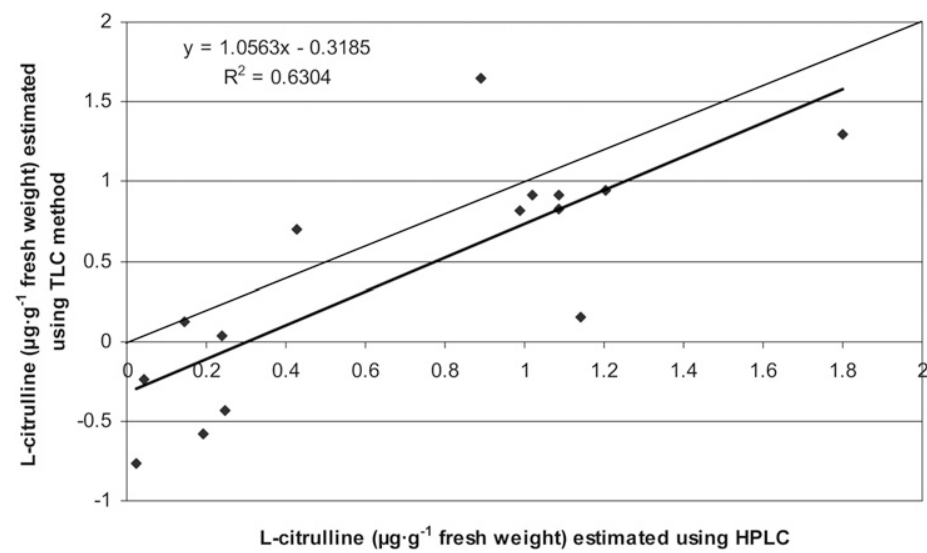

Fig. 1. Comparison of 14 watermelon samples comparing the described thin-layer chromatography (TLC) plate method to high-performance liquid chromatography (HPLC). Four samples were below the level of detection using TLC plates but small amounts of the amino acid were detected using HPLC. The slope of the best fit linear line (thin line) and the linear least square fit (bold line) are shown. The linear least square fit showed fair correlation between the methods. The best fit linear line indicates the position of a perfect correlation between the methods.

values of a small number of samples, HPLC should be used.

Environment effect. L-citrulline concentration was affected by environment (average of all fruit tested in Lane, $\mathrm{OK}=3.10 \mathrm{mg} \cdot \mathrm{g}^{-1}$ fresh weight and in College Station, $\mathrm{TX}=1.67 \mathrm{mg} \cdot \mathrm{g}^{-1}$ fresh weight) (Table 3). All cultigens had higher L-citrulline concentration in Lane, $\mathrm{OK}$, than College Station, TX (Table 2). When combined across locations for the 10 cultigens, there was not a significant environment by cultigens interaction $(P=0.475)$, but there was a significant difference between locations $(P=0.001$ level $)$ and cultigens $(P=0.05$ level, discussed in the next section). Our previous study (Davis et al., 2010) did not show a statistical difference for L-citrulline among three locations; however, fewer samples were tested in that study. Additionally, Fish and Bruton (2010) reported no difference in flesh L-citrulline levels in two locations in the same year, but again few samples (five per location) were tested in their study. The amount of environmental effect varies among cultigens. 'Charleston Gray' had the highest between environment mean difference $\left(2.50 \mathrm{mg} \cdot \mathrm{g}^{-1}\right.$ fresh weight) and 'Starbrite F1' and 'Minilee' had the most stable between environment mean difference $\left(0.85\right.$ and $0.86 \mathrm{mg} \cdot \mathrm{g}^{-1}$ fresh weight, respectively).

Within-cultigen differences were high in some cultigens. For example, 'Congo' had a 1.26 to $7.21 \mathrm{mg} \cdot \mathrm{g}^{-1}$ fresh sample deviation at one location. Of the lines in which 10 or more fruit were tested, 'AU-Jubilant' had the most stable L-citrulline expression, 2.23 to 4.03 $\mathrm{mg} \cdot \mathrm{g}^{-1}$ fresh weight deviation at one location (data not shown). It appears that environment does not significantly increase within-cultigen variation (relative SE of the 10 cultigens tested at each location was $\pm 35.3 \%$ for College Station, TX, and $\pm 32.9 \%$ for Lane, OK) (data not shown). 'AU-Jubilant' would be a likely candidate for development of cultivars having stable L-citrulline expression. However, 'AU-Jubilant' should be tested in more environments over several years to verify that conclusion.

The notable production differences between the two locations were (in Oklahoma) bare ground, fertigation, and watering when plants start to show water stress vs. (in Texas) black plastic mulch, pre-plant fertilization, and watering daily as needed based on evapotranspiration rates. Environmental conditions (data not shown) averaged over a 2week period before harvesting through the

Table 3. L-citrulline concentration differences between locations when comparing the 10 cultigens common to both locations. ${ }^{\mathrm{z}}$

\begin{tabular}{|c|c|c|}
\hline Location & $\begin{array}{c}\text { Mean } \\
\text { ( } \mu \mathrm{g} \text { L-citrulline } / \mathrm{g} \\
\text { fresh wt) }\end{array}$ & SD \\
\hline Lane, OK & $3.10 \mathrm{a}^{\mathrm{y}}$ & 1.01 \\
\hline College Station, TX & $1.67 \mathrm{~b}$ & 0.59 \\
\hline
\end{tabular}

${ }^{z}$ The values were estimated using a thin-layer chromatography plate method.

${ }^{y}$ Any two means within a column not followed by the same letter are significantly different at $P \leq$ 0.05 . 
last day of harvest [main growing period for L-citrulline accumulation according to Fish and Bruton (2010)] at each location revealed the following: the Texas location had an average air temperature of $3{ }^{\circ} \mathrm{C}$ higher than the Oklahoma production location. Average and total rainfall in Texas was approximately half that received in Oklahoma but because additional irrigation was applied at both locations, the amount of rain was probably not a factor in L-citrulline accumulation. Relative humidity and average total daily solar radiation were negligibly different between both locations and therefore most likely did not play a role in L-citrulline accumulation. Looking at these different environmental and production environments, it is likely the following have an effect on L-citrulline accumulation: soil temperature, moisture, and fertility and air temperature. Because previous reports (Akashi et al., 2001; Yokota et al., 2002) have shown that drought stress increases watermelon citrulline concentration in leaf tissue, it is provocative to speculate that drought stress can also increase the concentration of this healthful amino acid in fruit itself.

Because environment had such a noticeable effect on L-citrulline concentration, watermelon cultigens should be tested in multiple environments over multiple years to verify location and/or environmental effects and to determine which cultigens perform well under many different environmental conditions.

Cultigen differences. Because there was high within-cultigen variance for L-citrulline (discussed previously), the cultigens could not statistically be separated into low-, medium-, and high-expressing fruit. However, there was a statistical difference between the cultigens with the lowest and highest values (Table 1). Cultigens with the highest L-citrulline concentration (from 3.57 to $4.52 \mathrm{mg} \cdot \mathrm{g}^{-1}$ fresh weight) were 'Tom Watson', PI 306364, and 'Jubilee'. Cultigens with the lowest L-citrulline concentration were PI 189317, PI 161373, PI 164993, PI 181742, PI 162667, 'Medium Sugar Watermelon 28', 'Low Sugar Watermelon 194', PI 164992, and 'Low Sugar Watermelon 177 ' (from 1.09 to $2.18 \mathrm{mg} \cdot \mathrm{g}^{-1}$ fresh weight). Although the PI accessions tended to have lower L-citrulline than the elite cultivars, there was no correlation between amount of this amino acid and watermelon type (openpollinated vs. F1 hybrid), color (red, orange, salmon yellow, vs. white), fruit size, fruit shape, rind color or pattern, or fruit earliness (data not shown). Interestingly, cultigens with low soluble solids ( ${ }^{\circ}$ Brix) tended to have low L-citrulline concentration. However, cultigens with high soluble solids did not necessarily have higher L-citrulline (data not shown).

The L-citrulline concentrations for the watermelon in this study ( $2.97 \mathrm{mg} \cdot \mathrm{g}^{-1}$ fresh weight) were in the same range as previously published studies. Davis et al. (2010) reported an overall value of $2.4 \mathrm{mg} \cdot \mathrm{g}^{-1}$ fresh weight. Liu et al. (2010) reported an overall value of $2.27 \mathrm{mg} \cdot \mathrm{g}^{-1}$ fresh weight for mature diploid cultivars. Rimando and Perkins-Veazie (2005) reported an overall average of $2.4 \mathrm{mg} \cdot \mathrm{g}^{-1}$ fresh weight from 14 cultivars.

Rimando and Perkins-Veazie (2005) suggested that canary yellow and orange-fleshed fruit have higher L-citrulline values. In this study, there was no correlation between color and L-citrulline concentrations. 'Tendersweet Orange Flesh' was tested in this trial and in the Rimando and Perkins-Veazie trial and their average L-citrulline value for this cultigens was $1 \mathrm{mg} \cdot \mathrm{g}^{-1}$ fresh weight higher than our average value and is likely the result of environmental effects.

\section{Conclusion}

Genotype and environment both affected the amount of watermelon flesh L-citrulline with a mean of all fruit tested in Oklahoma of $3.10 \mathrm{mg} \cdot \mathrm{g}^{-1}$ fresh weight and in Texas of $1.67 \mathrm{mg} \cdot \mathrm{g}^{-1}$ fresh weight. There were large differences among cultigens for L-citrulline accumulated (1.09 to $4.52 \mathrm{mg} \cdot \mathrm{g}^{-1}$ fresh sample). The three highest cultigens were higher ('Tom Watson', PI 306364, and 'Jubilee'). These three lines could be used to develop improved, high L-citrulline cultivars. Additionally, L-citrulline concentration varied considerably within watermelon lines of both open-pollinated and hybrid watermelon. 'AU-Jubilant' demonstrated the most stable L-citrulline expression at one location. There was no correlation between L-citrulline concentration and watermelon type (open-pollinated or F1 hybrid) or color (red, orange, salmon yellow, or white).

\section{Literature Cited}

Akashi, K., C. Miyake, and A. Yokota. 2001 Citrulline, a novel compatible solute in droughttolerant wild watermelon leaves, is an efficient hydroxyl radical scavenger. FEBS Lett. 508: 438-442.

Boileau, T.W., Z. Liao, S. Kim, S. Lemeshow, J.W. Erdman, Jr., and S.K. Clinton. 2003. Prostate carcinogenesis in N-methyl-N-nitrosourea (NMU)testosterone-treated rats fed tomato powder, lycopene, or energy-restricted diets. J. Natl. Cancer Inst. 95:1578-1586.

Brenner, M. and A. Niederwieser. 1960. Chromatography of amino acids on thin layers of adsorbents. Experientia 16:378-383.

Chang, J.Y., R. Knecht, and D.G. Braun. 1983. Amino acid analysis in the picomole range by precolumn derivatization and high-performance liquid chromatography. Methods Enzymol. 91: 41-48.

Collins, J., G. Wu, P. Perkins-Veazie, K. Spears, P. Claypool, R. Baker, and B. Clevidence. 2007.
Watermelon consumption increases plasma arginine concentrations in adults. Nutrition 23: 261-266.

Curtis, E., I. Nicolis, C. Moinard, S. Osowska, N. Zerrouk, S. Benazeth, and L. Cynober. 2005. Almost all about citrulline in mammals. Amino Acids 29:177-205.

Davis, A.R., W. Fish, A. Levi, S. King, T. Wehner, and P. Perkins-Veazie. 2010. L-citrulline levels in watermelon cultivars from three locations. Cucurbit Genet. Coop. Rpt. 33:36-39.

FAOSTAT. 2009. 10 June 2011. <http://faostat.fao. org/site/567/DesktopDefault.aspx?PageID= 567 \#ancor/>

Figueroa, A., M.A. Sanchez-Gozalez, P.M. PerkinsVeazie, and B.H. Arjmandi. 2011. Effects of watermelon supplementation on aortic blood pressure and wave reflection in individuals with prehypertension: A pilot study. Amer. J. Hypertens 24:40-44.

Fish, W.W. and B.D. Bruton. 2010. Quantification of L-citrulline and other physiologic amino acids in watermelon and various cucurbits. In: Thies, J.A., S. Kousik, and A. Levi (eds.). Cucurbitaceae 2010. Proc. Amer. Soc. Hort. Sci. 10:152-154

Krause, I., A. Bockhardt, H. Neckermann, T. Henle, and H. Klostermeyer. 1995. Simultaneous determination of amino acids and biogenic amines by reversed-phase high-performance liquid chromatography of the dabsyl derivatives. J. Chromatography 715:67-79.

Liu, W., S. Zhao, Z. Cheng, X. Wan, Z. Yan, and S. King. 2010. Lycopene and citrulline contents in watermelon (Citrullus lanatus) fruit with different ploidy and changes during fruit development. In: Sun, X. (ed.). Proc. 4th Intl. Symp. on Cucurbits, Acta Hort. ISHS 871: 543-550.

Mandel, H., N. Levy, S. Izkovitch, and S.H. Korman. 2005. Elevated plasma citrulline and arginine due to consumption of Citrullus vulgaris (watermelon). J. Inherit. Metab. Dis. 28:467-472.

Masabni, J., J. Anciso, P. Lillard, and J. Dainello. 2011. Texas commercial vegetable production guide. Texas AgriLife Extension. Texas A\&M Univ. Publication B-6159.

Motes, J. and G. Cuperus. 1995. Cucurbit production and pest management. Coop. Ext. Okla. Serv., Okla. State Univ. Circular E-853.

Rimando, A.M. and P. Perkins-Veazie. 2005. Determination of citrulline in watermelon rind. $\mathrm{J}$. Chromatography 1078:196-200.

Sethuraman, S., T.L. Lee, and S. Tachibana. 2004 Simple quantitative HPLC method for measuring physiologic amino acids in cerebrospinal fluid without pretreatment. Clin. Chem. 50:665669.

Tarazona-Díaz, M.P., J. Viegas, M. Moldao-Martinsc, and E. Aguayoa. 2011. Bioactive compounds from flesh and by-product of fresh-cut watermelon cultivars. J. Sci. Food Agr. 91:805-812.

Tedesco, T.A., S.A. Benford, R.C. Foster, and L.A. Barness. 1984. Free amino acids in Citrullus vulgaris (watermelon). Pediatrics 73:879.

Yokota, A., S. Kawasaki, M. Iwano, C. Nakamura, C. Miyake, and K. Akashi. 2002. Citrulline and DRIP-1 protein (ArgE homologue) in drought tolerance of wild watermelon. Ann. Bot. (Lond.) 89:825-832. 